\title{
CK2a, over-expressed in human malignant pleural mesothelioma, regulates the Hedgehog signaling pathway in mesothelioma cells
}

Shulin Zhang ${ }^{1,2+}$, Yi-Lin Yang ${ }^{2 \dagger}$, Yucheng Wang ${ }^{3}$, Bin You ${ }^{2,4}$, Yuyuan Dai ${ }^{2}$, Geraldine Chan², David Hsieh2, II-Jin Kim², Li Tai Fang ${ }^{2}$, Alfred Au ${ }^{5}$, Hubert J Stoppler ${ }^{6}$, Zhidong $\mathrm{Xu}^{2}$, David M Jablons ${ }^{2}$ and Liang You ${ }^{2 *}$

\begin{abstract}
Background: The Hedgehog $(\mathrm{Hh})$ signaling pathway has been implicated in stem cell maintenance and its activation is aberrant in several types of cancer including mesothelioma. Protein kinase CK2 affects several cell signaling pathways through the mechanism of phosphorylation.

Methods: Protein and mRNA levels of CK2a and Gli1 were tested by quantitative RT-PCR and immunohistochemistry staining in mesothelioma samples and cell lines. Down-regulated Gli1 expression and transcriptional activity were demonstrated by RT-PCR, Western blot and luciferase reporter assay.

Results: In this study, we show that CK2a is over-expressed and a positive regulator of Hegdehog/Gli1 signaling in human malignant pleural mesothelioma. First of all, we found that the mRNA levels of CK2a and Gli1 were broadly elevated and correlated $(n=52, r=0.401, P<0.05)$, compared with LP9 (a normal mesothelial cell line). We then investigated their expression at the protein level, and found that all the 7 mesothelioma cell lines tested showed positive staining in CK2a and Gli1 immunohistochemistry. Correlation analysis by Pearson test for CK2 $a$ and Gli1 expression in the 75 mesothelioma tumors and the 7 mesothelioma cell lines showed that the two protein expression was significantly correlated $(n=82, r=0.554, P<0.01)$. Furthermore, we demonstrated that Gli1 expression and transcriptional activity were down-regulated after CK2a was silenced in two mesothelioma cell lines (H28 and H2052). CK2a siRNA also down-regulated the expression of Hh target genes in these cell lines. Moreover, treatment with a small-molecule CK2a inhibitor CX-4945 led to dose-dependent inhibition of Gli1 expression and transcriptional activity. Conversely, forced over-expression of CK2a resulted in an increase in Gli1 transcriptional activity in $\mathrm{H} 28$ cells.
\end{abstract}

Conclusions: Thus, we report for the first time that over-expressed CK2a positively regulate Hh/Gli1 signaling in human mesothelioma.

Keywords: CK2a, Hedgehog, Gli1, IHC, Mesothelioma

\section{Background}

Protein kinase CK2 (formerly known as casein kinase II) is a highly conserved serine/threonine kinase that phosphorylates more than 300 proteins [1]. CK2 has a heterotetrameric structure consisting of two catalytic subunits $(42-\mathrm{kDa} \alpha$ or $\left.38-\mathrm{kDa} \alpha^{\prime}\right)$ and the regulatory subunit $(28-\mathrm{kDa} \beta)$, forming

\footnotetext{
* Correspondence: Liang.You@ucsfmedctr.org

${ }^{\dagger}$ Equal contributors

${ }^{2}$ Thoracic Oncology Laboratory, Department of Surgery, Helen Diller Family Comprehensive Cancer Center, University of California San

Francisco, San Francisco, CA 94143, USA

Full list of author information is available at the end of the article
}

the configurations $\alpha 2 \beta 2, \alpha \alpha^{\prime} \beta 2$ and $\alpha^{\prime} 2 \beta 2$. CK2 is a multifunctional protein kinase [2], that has been shown to be involved in nearly every aspect of cell proliferation and survival [3-5]. The level of CK2 $\alpha$ expression is tightly regulated in normal cells [6], and increased CK2 $\alpha$ level and activity has been consistently observed in a variety of human cancers [7-9]. For instance, a high level and/or nuclear localization of CK2 $\alpha$ is a marker of poor prognosis for patients with acute myeloid leukemia, chronic lymphocytic leukemia, prostate cancer and gastric cancer [10-13]. In addition, stable knockdown CK2 $\alpha$ has recently been shown 
to inhibit cell migration and invasion of hepatocellular carcinoma [14]. Studies also revealed that CK2 affects several cell signaling pathways, including PI3K, NFkB and Wnt $[6,15,16]$.

The Hedgehog (Hh) family of secreted proteins, which consists of Sonic, Indian and Desert Hedgehog, plays important roles in mammalian development and in stem cell maintenance $[17,18]$. The $\mathrm{Hh}$ pathway is activated at the cell surface by the Hh ligand binding to its receptor Patched (Ptc), resulting in derepression of the effector protein, a G-protein-coupled receptor, Smoothened (Smo) [19]. Ultimately, Smo activates the Gli family of transcription factors and target genes. There are three Gli proteins in humans: Gli1 activates Hh target genes, Gli2 acts both as activator and repressor of Hh target genes, while Gli3 acts as a repressor of Hh target genes [20,21]. Deregulation of $\mathrm{Hh} / \mathrm{Gli}$ signaling is implicated as an initiating or maintaining factor in the progression of various cancers, including basal cell carcinomas, medulloblastomas, leukemia, gastrointestinal, lung, ovarian, breast and prostate cancers [20,22]. For instance, the Gli1 gene is amplified in human glioma and activated in basal cell carcinoma [23-25]. Transgenic over-expression of Gli1 in mice leads to the development of basal cell carcinoma [26]. Hedgehog pathway inhibitor GDC-0449 is an FDA-approved drug for treatment of metastatic basal cell carcinoma.

Malignant pleural mesothelioma (mesothelioma) is an aggressive cancer with poor prognosis that originates mostly from the pleura of the lung. Mesothelioma is associated with occupational exposure to asbestos [27]. It has been suggested that mesotheliomas contain cancer stem cells and their stem cell characteristics are thought to confer therapy-resistance [28]. Activated stem cell signaling in patients has already been suggested in mesothelioma. For instance, cells staining positive for nuclear beta-catenin, a marker for Wnt signaling activation, have been reported in a few studies [29,30].

Recently, Hh/Gli1 signaling was reported to be aberrantly activated in human mesothelioma [31,32]. To date, there is no evidence for the status of CK2 in mesothelioma. The relationship between CK2 and Hh/Gli1 signaling in mesothelioma is unknown. We therefore sought to detect CK2 $\alpha$ and Gli1 expression in primary mesothelioma tissues and cell lines, and to analyze their relationship.

\section{Methods}

\section{Cell culture and small molecule treatment}

Nine human mesothelioma cell lines (H28, H290, H2052, 211H, H2452, MS-1, H226, REN and H513) and a normal pleura cell line (LP9) were obtained from American Type Culture Collections (Manassas, VA). Cells were routinely maintained in RPMI-1640 supplemented with 10\% heatinactivated fetal bovine serum, penicillin $(100 \mu \mathrm{g} / \mathrm{ml})$ and streptomycin $(100 \mu \mathrm{g} / \mathrm{ml})$. All cells were routinely cultivated at $37^{\circ} \mathrm{C}$ in a humid incubator with $5 \% \mathrm{CO} 2$. Treatment with CX-4945 (Synkinase, San Diego, CA) and TBB (Sigma, St. Louis, MO) dissolved in DMSO was administered at several dosages. Cells were grown in medium for 48 hours after treatment. Cell proliferation in vitro was assessed using a CellTiter-Glo Luminescent cell viability assay (Promega Corporation, Madison, WI), according to the manufacturer's protocol [33].

\section{Tissue samples and immunohistochemistry (IHC)}

Fresh mesothelioma tissues were obtained from patients who were undergoing surgical resection of the primary tumor. All human tissue samples were obtained and analyzed in accordance with procedures approved by the institutional review board of the University of California, San Francisco (IRB H8714-22 942-01). The tissue microarray sections were immunostained as previously described [33]. Anti-CK $2 \alpha$ antibody was from Millipore (Billerica, MA). Anti-Gli1 antibody was from Cell Signaling (Beverly, MA). The following scoring system was used: - , no stain; +, weak staining $(10 \%$ or above stained cellularity considered as positive); ++ , moderate staining ( $30 \%$ or above stained cellularity considered as positive); +++ , strong staining (50\% or above stained cellularity considered as positive). All scoring was done under low power objective lens $(10 \times)$ with a Zeiss Axioscop 2 microscope (Carl Zeiss Inc, Germany). Images were taken under $10 x$ or 40x objective lens.

\section{SiRNA and plasmid DNA transfection}

CK2 $\alpha$ siRNA (ON-TARGET plus SMARTpool) and control siRNA were purchased from Thermo Scientific (Waltham, MA). Cells were seeded in a 6-well plate as $10^{5}$ cells/well one day before transfection, with a target of 30-50\% confluency at the time of transfection. Cells were transfected with $50 \mathrm{nmol} / \mathrm{L}$ of siRNA using Lipofectamine RNAiMAX (Invitrogen, Carlsbad, CA) according to the manufacturer's protocol. Adequate inhibition of the siRNAmediated knockdown was confirmed by Western blot. The pcDNA3.1-CK $2 \alpha$ or control pcDNA3.1-LacZ plasmid vectors were then transfected into the $\mathrm{H} 28$ cells $(0.5 \mu \mathrm{g} / \mathrm{ml}$ in 24-well plate) using Lipofectamine 2000 transfection reagent (Invitrogen), according to the manufacturer's protocol. Cells were harvested for RT-PCR and Western blot or used in reporter assays at 48 hours post-transfection.

\section{RNA isolation, cDNA synthesis and semi-quantitative RT-PCR}

RNA was isolated using the RNeasy Mini kit (Qiagen, Valencia, CA). Human Lung Total RNA was purchased from Applied Biosystems (Foster City, CA). Five-hundred ng of total RNA was converted into $20 \mu \mathrm{l}$ cDNA using iScript cDNA Synthesis Kits (Bio-Rad, Hercules, CA,) 
according to the manufacturer's recommendations. PCR bands were visualized under UV light and photographed.

\section{Quantitative RT-PCR}

A total of $2 \mu \mathrm{l}$ of the reverse transcription reaction were used as template for real-time detection using TaqMan Technology on an Applied Biosystems 7000 sequence detection system (Applied Biosystems). Gene expression was quantified for the tested genes and endogenous control gene b-glucuronidase (GUSB) using commercially available primer and probe sequences (Applied Biosystems). Relative mRNA level was calculated by normalizing the gene expression levels of tested genes to that of the control GUSB gene.

\section{Western blot analysis}

Whole protein was extracted by M-PER Mammalian Protein Extraction Reagent (Thermo) from cell lines added with Phosphatase Inhibitor Cocktail Set II (Calbiochem, San Diego, CA) and Complete Protease Inhibitor Cocktails (Roche, Lewes, UK) according to manufacturers' protocols. The proteins were separated on 4-15\% gradient SDSpolyacrylamide gels and transferred to Immobilon-P membranes (Millipore, Bellerica, MA). The following primary antibodies were used: anti-CK2 $\alpha$ (Millipore), anti-Gli1 (Cell Signaling), and anti-GAPDH (Trevigen,
Gaithersburg, MD). After being incubated with appropriate secondary antibodies, the antigen-antibody complexes were detected by using an ECL blotting analysis system (Amersham Pharmacia Biotech, Piscataway, NJ). Digital images were prepared using Adobe Photoshop CS3.

\section{Luciferase reporter assays}

To measure Gli-mediated Hh transcriptional activity, the luciferase reporter constructs, $8 \times$ wild-type Gli binding site $\left(8 \times\right.$ Gli ${ }^{\text {wt }}$ Luc) or $8 \times$ mutant Gli binding site (8x Gli ${ }^{\text {mut }}$ Luc) plasmids [34] and a human Gli1 expression vector (pcDNA3.1-Gli1) were co-transfected into H28 cells in 24-well plates. The Renilla luciferase pRL-TK plasmid (Promega, Madison, WI), whose expression is driven by the housekeeping thymidine kinase gene promoter, was co-transfected to normalize for transfection efficiency. All transfection experiments were performed using the Lipofectamine2000 (Invitrogen) in accordance with the manufacturer's instructions. After $24 \mathrm{~h}$ cells were lysed and luciferase assays were performed as described previously [35]. Results are expressed as fold induction, which is the ratio of luciferase activity induced in Gli-transfected cells relative to basal luciferase activity in control transfected $\mathrm{H} 28$ cells. All experiments were performed in triplicate; means and standard errors were calculated using Student's t-test.

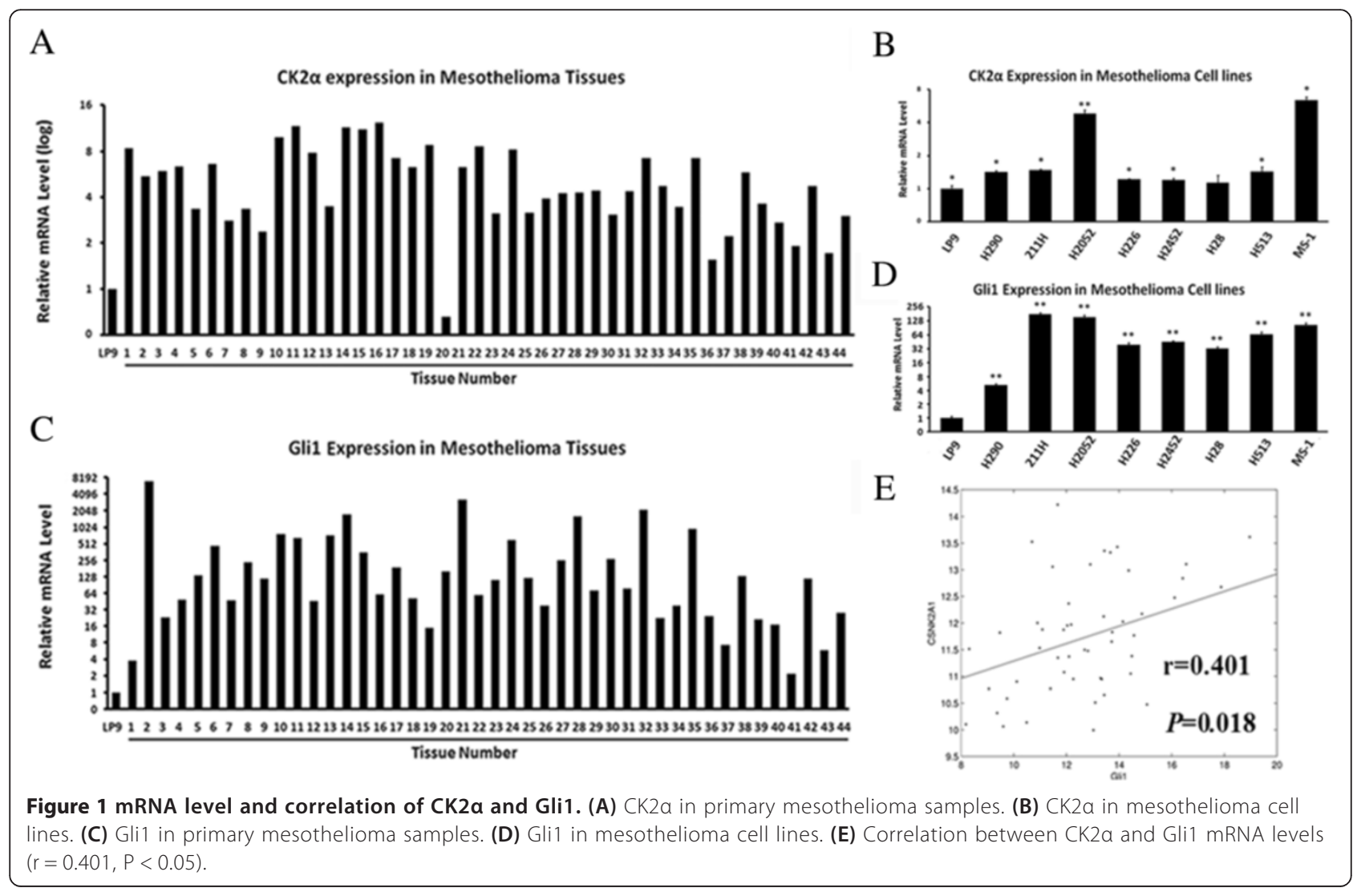




\section{Statistical analysis}

Data were expressed as mean \pm standard deviation (SD) from three independent experiments. All of the statistical analyses were performed using SPSS 13.0 for Windows software system (SPSS Inc, Chicago, IL). Student's t-test was used to compare the differences among groups. Pearson product correlation tests (in the form of a correlation matrix) were used to analyze the mRNA and protein level of CK $2 \alpha$ and Gli1. A significant difference was declared if the $\mathrm{P}$ value from a two-tailed test was less than 0.05 (* $\mathrm{P}<0.05, * \mathrm{P}<0.01)$.

\section{Results}

\section{Quantitative RT-PCR of CK2a and Gli1}

Quantitative RT-PCR was used to examine the mRNA level of CK2 $\alpha$ and Gli1 in 44 primary mesothelioma samples and 8 mesothelioma cell lines (H28, H290, H2052, 211H, H2452, MS-1, H226 and H513). As shown in Figure 1A, 97.7\% (43/44) primary samples showed dramatically elevated CK $2 \alpha$ mRNA level, compared with a normal pleura cell line LP9. In analysis of the cell lines, 87.5\% (7/8) showed significantly elevated CK $2 \alpha$ expression mRNA level, compared with LP9 (Figure 1B). All of the primary samples and the cell lines showed elevated Gli1 mRNA level, compared with LP9 (Figure 1C-D).

\section{Immunohistochemistry of CK2 $a$ and Gli1 in mesothelioma} Both CK $2 \alpha$ and Gli1 genes are over-expressed in a variety of cancers [36,37]. However, whether CK $2 \alpha$ is overexpressed in mesothelioma is unknown. First, by using the immunohistochemistry (IHC) staining, we detected the protein level of $\mathrm{CK} 2 \alpha$ and Gli1 in 75 primary mesothelioma samples and 7 cell lines (H28, H290, 211H, H2452, MS-1, H226 and REN) of the tissue microarray sections. The positive or negative results of $\mathrm{CK} 2 \alpha$ and Gli1 staining in these sections are shown in Figure 2 and Tables 1, 2 and 3. Lung cancer cell line A427 with strong positive $(+++)$ staining of CK2 $\alpha$ and Gli1 was used as a positive control. In the primary mesothelioma samples (Figure 2A, C and Tables 1 and 2), the overall positive ratios of $\mathrm{CK} 2 \alpha$ and Gli1 were both $93.3 \%$ (70/75). The moderate and strong positive $(++/+++)$ ratio was $69.3 \%$ $(52 / 75)$ in CK $2 \alpha$ staining and $50.6 \%(38 / 75)$ in Gli1 staining. The strong positive $(+++)$ ratio was high $(40 \%)$ in CK $2 \alpha$ staining. The strong positive ratio of Gli1 staining was lower $(17.3 \%)$ than that of $\mathrm{CK} 2 \alpha$ staining. In

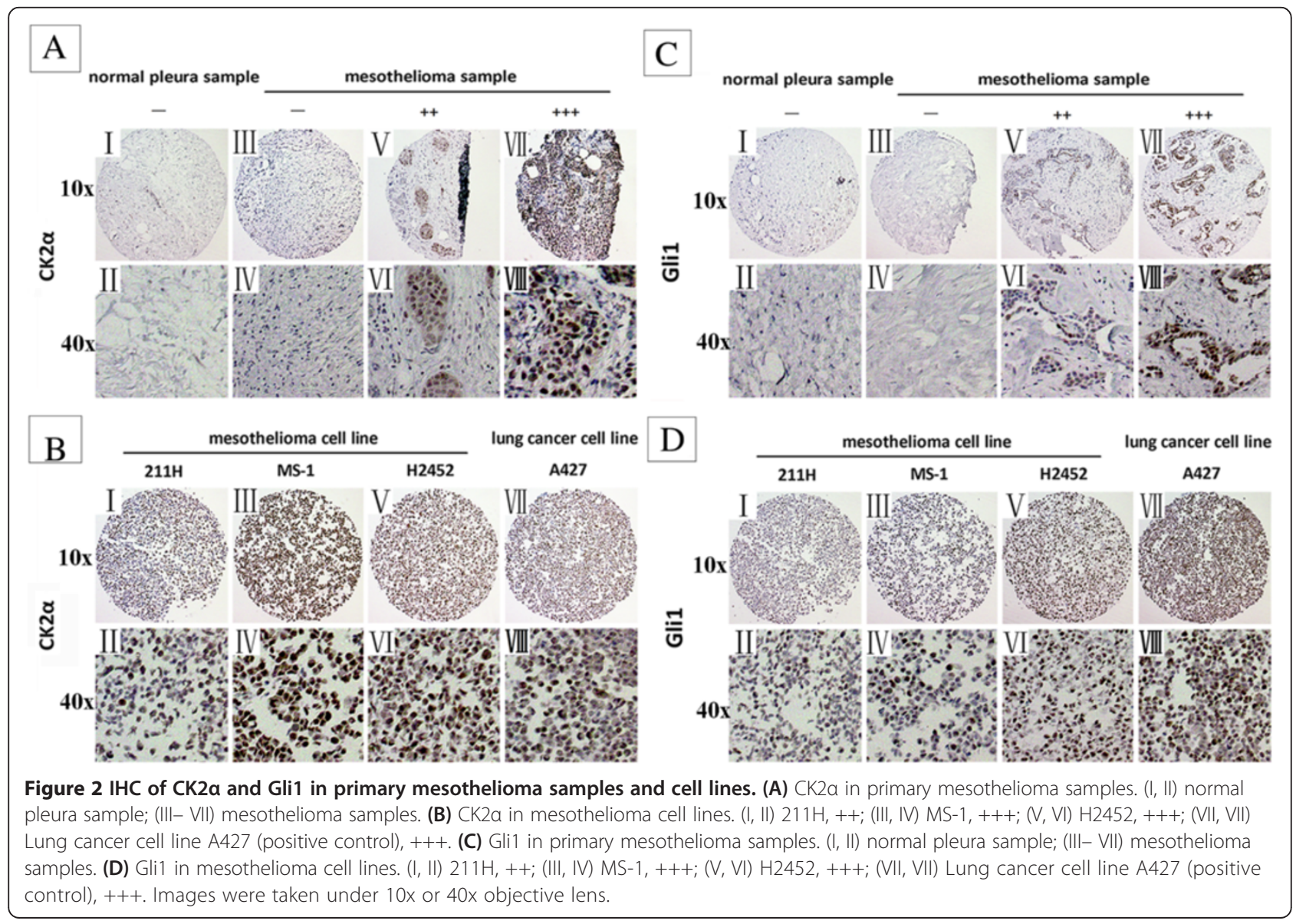


Table 1 Immunohistochemistry findings from human mesothelioma samples

\begin{tabular}{|c|c|c|c|c|c|}
\hline Sample no. & IHC of anti-CK2a & IHC of anti-Gli1 & Sample no & IHC of anti-CK2a & IHC of anti-Gli1 \\
\hline T01 & - & + & T45 & + & + \\
\hline T02 & + & ++ & T46 & +++ & +++ \\
\hline T03 & ++ & + & $\mathrm{T} 47$ & +++ & + \\
\hline T04 & + & + & $\mathrm{T} 48$ & + & + \\
\hline T05 & + & + & T49 & ++ & ++ \\
\hline T06 & ++ & ++ & T50 & +++ & ++ \\
\hline T07 & +++ & ++ & T51 & +++ & ++ \\
\hline T08 & ++ & + & T52 & +++ & - \\
\hline T09 & + & ++ & T53 & +++ & ++ \\
\hline $\mathrm{T} 10$ & ++ & ++ & T54 & ++ & + \\
\hline $\mathrm{T} 11$ & +++ & +++ & T55 & +++ & + \\
\hline $\mathrm{T} 12$ & +++ & ++ & T56 & ++ & + \\
\hline $\mathrm{T} 13$ & +++ & + & T57 & ++ & ++ \\
\hline T14 & + & + & T58 & +++ & +++ \\
\hline T15 & +++ & ++ & T59 & ++ & +++ \\
\hline T16 & ++ & ++ & $\mathrm{T} 60$ & - & ++ \\
\hline $\mathrm{T} 17$ & ++ & + & T61 & + & + \\
\hline T18 & + & + & T62 & ++ & ++ \\
\hline T19 & ++ & + & T63 & +++ & + \\
\hline T20 & +++ & +++ & T64 & +++ & ++ \\
\hline T21 & +++ & +++ & T65 & ++ & +++ \\
\hline T22 & - & - & T66 & ++ & + \\
\hline $\mathrm{T} 23$ & +++ & ++ & T67 & +++ & +++ \\
\hline T24 & + & +++ & T68 & +++ & +++ \\
\hline T25 & +++ & ++ & T69 & + & + \\
\hline T26 & +++ & +++ & $\mathrm{T} 70$ & + & + \\
\hline T27 & ++ & ++ & $\mathrm{T} 71$ & +++ & +++ \\
\hline T28 & +++ & + & $\mathrm{T} 72$ & +++ & + \\
\hline T29 & +++ & ++ & $\mathrm{T} 73$ & +++ & + \\
\hline T30 & ++ & + & T74 & - & - \\
\hline T31 & +++ & ++ & T75 & + & ++ \\
\hline T32 & ++ & + & N1 & - & - \\
\hline T33 & + & - & N2 & + & + \\
\hline T34 & + & + & N3 & + & - \\
\hline T35 & + & + & N4 & - & - \\
\hline T36 & + & + & N5 & - & - \\
\hline T37 & ++ & + & N6 & - & - \\
\hline T38 & - & - & $\mathrm{H} 226$ & + & ++ \\
\hline T39 & +++ & ++ & REN & + & ++ \\
\hline $\mathrm{T} 40$ & +++ & ++ & $\mathrm{H} 290$ & +++ & +++ \\
\hline T41 & ++ & + & $211 \mathrm{H}$ & ++ & ++ \\
\hline T42 & ++ & ++ & H2452 & +++ & +++ \\
\hline T43 & + & +++ & $\mathrm{H} 28$ & ++ & + \\
\hline T44 & ++ & + & MS-1 & +++ & +++ \\
\hline
\end{tabular}

$\mathrm{N}=$ normal tissue; $\mathrm{T}=$ tumour tissue; $\mathrm{IHC}=$ immunohistochemistry; $-=$ no stain + + = weak stain $+++=$ moderate stain $;+++=$ strong stain. 
Table 2 Positive and negative number and ratio of CK2 $a$ and Gli1 in 75 primary mesothelioma samples

\begin{tabular}{llllll}
\hline & - Number (ratio) & + Number (ratio) & ++ Number (ratio) & +++Number (ratio) & Total (ratio) \\
\hline CK2a & $5(6.67 \%)$ & $18(24.0 \%)$ & $22(29.3 \%)$ & $30(40.0 \%)$ & $75(100 \%)$ \\
Gli1 & $5(6.67 \%)$ & $32(42.7 \%)$ & $25(33.3 \%)$ & $13(17.3 \%)$ & $75(100 \%)$ \\
\hline
\end{tabular}

specimens of normal pleural tissue, CK2 and Gli1 staining was negative $(-)$ or weak $(+)$ at the cell membrane or in the region of cytoplasm near the membrane (Figure 2A, C and Tables 1 and 3). In all the 7 cell lines tested, both $\mathrm{CK} 2 \alpha$ and Gli1 showed positive staining (Figure 2B, D and Table 1 ). For CK2 $\alpha$ staining, H290, H2452 and MS-1 were strong positive $(+++)$, while REN and H226 were weaker $(+)$. For Gli1 staining, H290, H2452 and MS-1 were strong positive $(+++)$, while $\mathrm{H} 28$ was weaker $(+)$. These results suggest an aberrant over-expression of CK2 and Gli1 in mesothelioma.

\section{Correlation between CK2a and Gli1}

To analyze the relationship between CK2 $\alpha$ and Gli1 in mesothelioma, we performed a Pearson product correlation test on CK $2 \alpha$ and Gli1 staining in the 75 primary samples and the 7 cell lines. CK2 $\alpha$ and Gli1 were mildly correlated at the protein level $(\mathrm{n}=82, \mathrm{r}=0.554, \mathrm{P}<0.01$, Table 4). We then investigated their relationship at the mRNA level, and found that CK $2 \alpha$ and Gli1 were also broadly elevated and correlated $(\mathrm{n}=52, \mathrm{r}=0.401$, $\mathrm{P}<0.05$, Figure $1 \mathrm{E}$ and Table 4 ) at the mRNA level.

\section{Down-regulation of $\mathrm{Hh} / \mathrm{Gli} 1$ signaling by $\mathrm{CK} 2 \mathrm{a}$ knockdown}

To investigate whether CK2 has an effect on the Hh pathway, we silenced CK $2 \alpha$ expression for $48 \mathrm{~h}$ using CK2 $\alpha$ siRNA in $\mathrm{H} 28$ and $\mathrm{H} 2052$ cell lines. It has been previously shown that $48 \mathrm{~h}$ of $\mathrm{CK} 2 \alpha$ siRNA treatment is efficient to knockdown $\mathrm{CK} 2 \alpha$ protein expression in the treated cells [38-41]. The efficiency of RNA interference was monitored by semi-quantitative RT-PCR and Western blot (Figure $3 \mathrm{~A}$ and $\mathrm{B}$ ). The corresponding mRNA and protein levels of $\mathrm{CK} 2 \alpha$ in $\mathrm{H} 28$ and $\mathrm{H} 2052$ cell lines decreased dramatically (Figure 3A and B, upper lane). Expression of Gli11 was inhibited after CK $2 \alpha$ knockdown in the two cell lines (Figure $3 \mathrm{~A}$ and $\mathrm{B}$, middle lane).

To confirm whether $\mathrm{CK} 2 \alpha$ positively regulates $\mathrm{Hh} / \mathrm{Gli1}$ signaling, we performed a luciferase reporter assay to detect the transcriptional activity of the pathway. Silencing

Table 3 Positive and negative number of CK2 $a$ and Gli1 in normal pleura samples

\begin{tabular}{llllll}
\hline & - Number & + Number & ++ Number & +++Number & Total \\
\hline CK2a & 4 & 2 & 0 & 0 & 6 \\
Gli1 & 5 & 1 & 0 & 0 & 6 \\
\hline
\end{tabular}

of CK $2 \alpha$ in $\mathrm{H} 28$ cells resulted in a significant decrease ( $48 \%$ at $50 \mu \mathrm{M}, \mathrm{P}<0.01$, Figure $3 \mathrm{C}$ ) in the Gli reporter activity, compared with the non-targeting siRNA (control). To study the effects of CK $2 \alpha$ knockdown on Hh/Gli1 signaling, quantitative RT-PCR was performed to compare the levels of Gli1 and Ptc1 mRNA between wildtype and CK $2 \alpha$ knockdown cell lines. The mRNA level of the two Hh target genes decreased significantly $(\mathrm{P}<0.01$, Figure 3D) after CK $2 \alpha$ knockdown. In normal mesothelial LP9 cells, decrease in mRNA level of the two Hh target genes was also detected using quantitative RTPCR (Additional file 1: Figure S1A). These results suggest a depressed transcriptional activity of Hh/Gli1 signaling after $\mathrm{CK} 2 \alpha$ knockdown.

\section{Down-regulation of Gli1 expression and transcriptional activity by $\mathrm{CK} 2 \mathrm{a}$ inhibitor}

To extend our findings to clinical applications, we used a small-molecule CX-4945 (5-(3-chlorophenylamino)benzo [c][2,6]naphthyridine-8-carboxylic acid), a first-in-class, selective, oral inhibitor of CK $2 \alpha$ under investigation in Phase 1 clinical trials [42]. Cells were treated with multiple concentrations of CX-4945 (0.01, 0.03, 0.1, 0.3, 1, 3, 10 and $30 \mu \mathrm{M})$, or with the vehicle DMSO for 72 hours. The cell proliferation assay demonstrated that treatments with CX-4945 led to cell growth inhibition in a dose-dependent manner, both in H28 and H2052 cell lines (IC50 values were $7.2 \mu \mathrm{M}$ in $\mathrm{H} 28$ and $2.0 \mu \mathrm{M}$ in $\mathrm{H} 2052$, respectively, Figure 4A). Normal mesothelial LP9 cells also showed a dose-dependent inhibition on cell growth by CX-4945 treatment (IC50 values is $3.3 \mu \mathrm{M}$, Additional file 1: Figure S1B). After treatment with CX-4945, Gli1 expression decreased noticeably at the dosage level of $3 \mu \mathrm{M}$ in $\mathrm{H} 2052$ or $10 \mu \mathrm{M}$ in $\mathrm{H} 28$, and decreased to minimal at $10 \mu \mathrm{M}$ in $\mathrm{H} 2052$ (Figure 4C). We further demonstrated that treatment with CX-4945 led to a dosedependent decrease in Gli reporter activity in the $\mathrm{H} 28$ cells. The decrease was $47 \%(\mathrm{P}<0.05)$ in the presence of $3 \mu \mathrm{M}$ $\mathrm{CX}-4945$ or $70 \%(\mathrm{P}<0.01)$ in the presence of $10 \mu \mathrm{M} \mathrm{CX}$ 4945 (Figure 4B). TBB (4,5,6,7-tetrabromobenzotriazole),

Table 4 Correlation analysis of CK2a and Gli1 in mesothelioma

\begin{tabular}{llll}
\hline & N & r & $\boldsymbol{P}$ \\
\hline mRNA & 52 & 0.401 & 0.018 \\
Protein & 82 & 0.554 & 0.000 \\
\hline
\end{tabular}




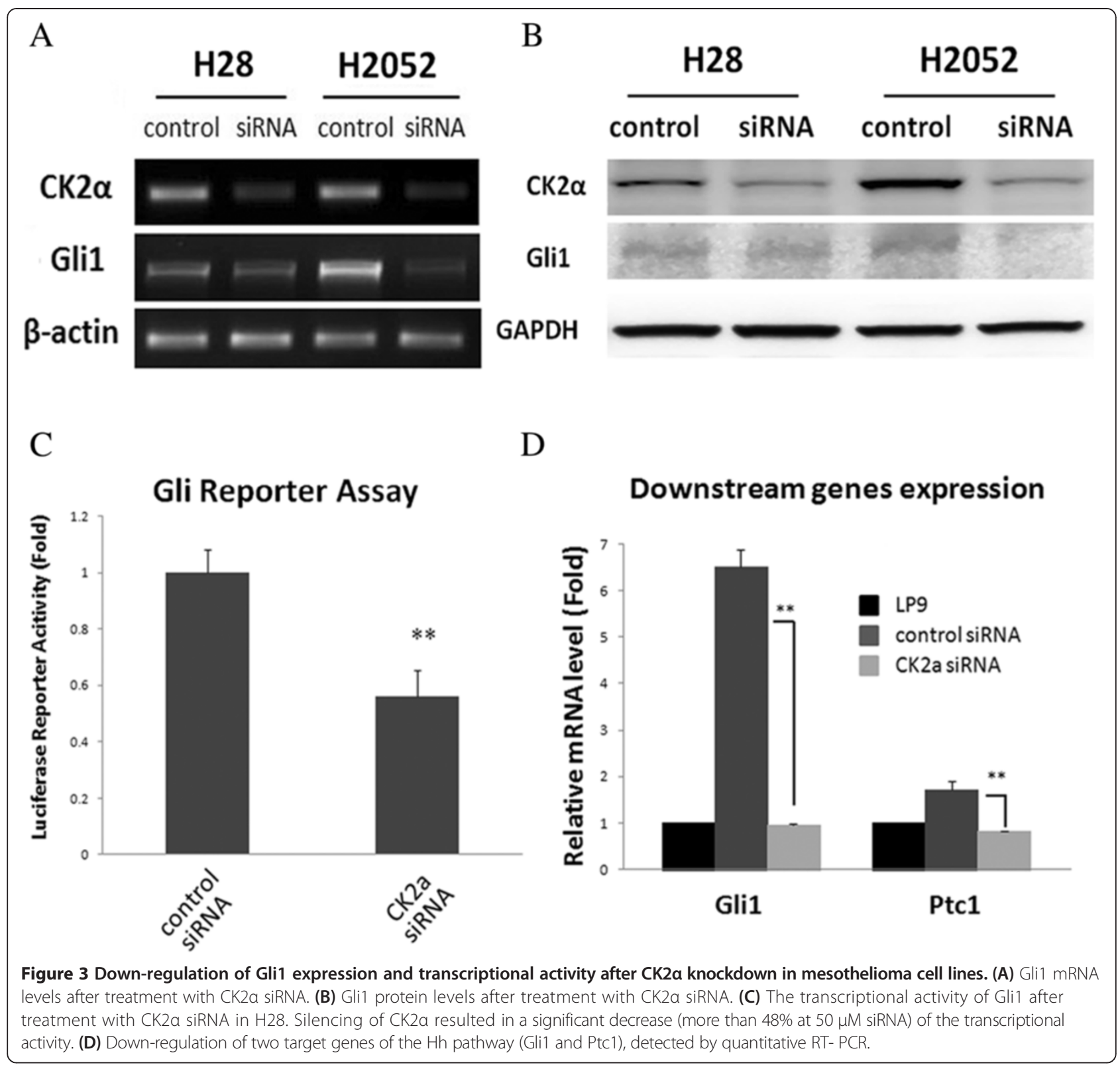

a well-known inhibitor of CK2 $\alpha$ [43] was used as a positive control. $10 \mu \mathrm{M}$ TBB led to an $80 \%$ decrease of Gli1 transcriptional activity.

Transcriptional activation of Gli1 by forced overexpression of $\mathrm{CK} 2 \mathrm{a}$

To confirm whether CK2 positively affects the transcriptional activity of Gli1, we transfected $\mathrm{H} 28$ cells with either a pcDNA3.1-CK $2 \alpha$ or control pcDNA3.1-LacZ plasmid. As expected, CK $2 \alpha$ over-expression, detected by Western blot (Figure 5A), was attributed to the activation of Gli1 in H28 cells. The reporter assay also showed a significant (>10-fold, P < 0.01) increase of Gli1 transcriptional activity (Figure 5B). These findings suggest that forced over- expression of $\mathrm{CK} 2 \alpha$ leads to a transcriptional activation of Gli1.

\section{Discussion}

Our results suggest that $\mathrm{CK} 2 \alpha$ is over-expressed and positively regulates $\mathrm{Hh} / \mathrm{Gli1}$ signaling in human malignant pleura mesothelioma. This is supported by several lines of evidence. First, broadly aberrant over-expression of CK2 was demonstrated in most of the primary mesothelioma samples and cell lines we tested. Second, we found a statistically mild correlation between CK2 and Gli1 expression both at the mRNA and protein levels. Third, in experimental studies of mesothelioma cell lines, CK $2 \alpha$ inhibition by siRNA or small-molecular inhibitor 


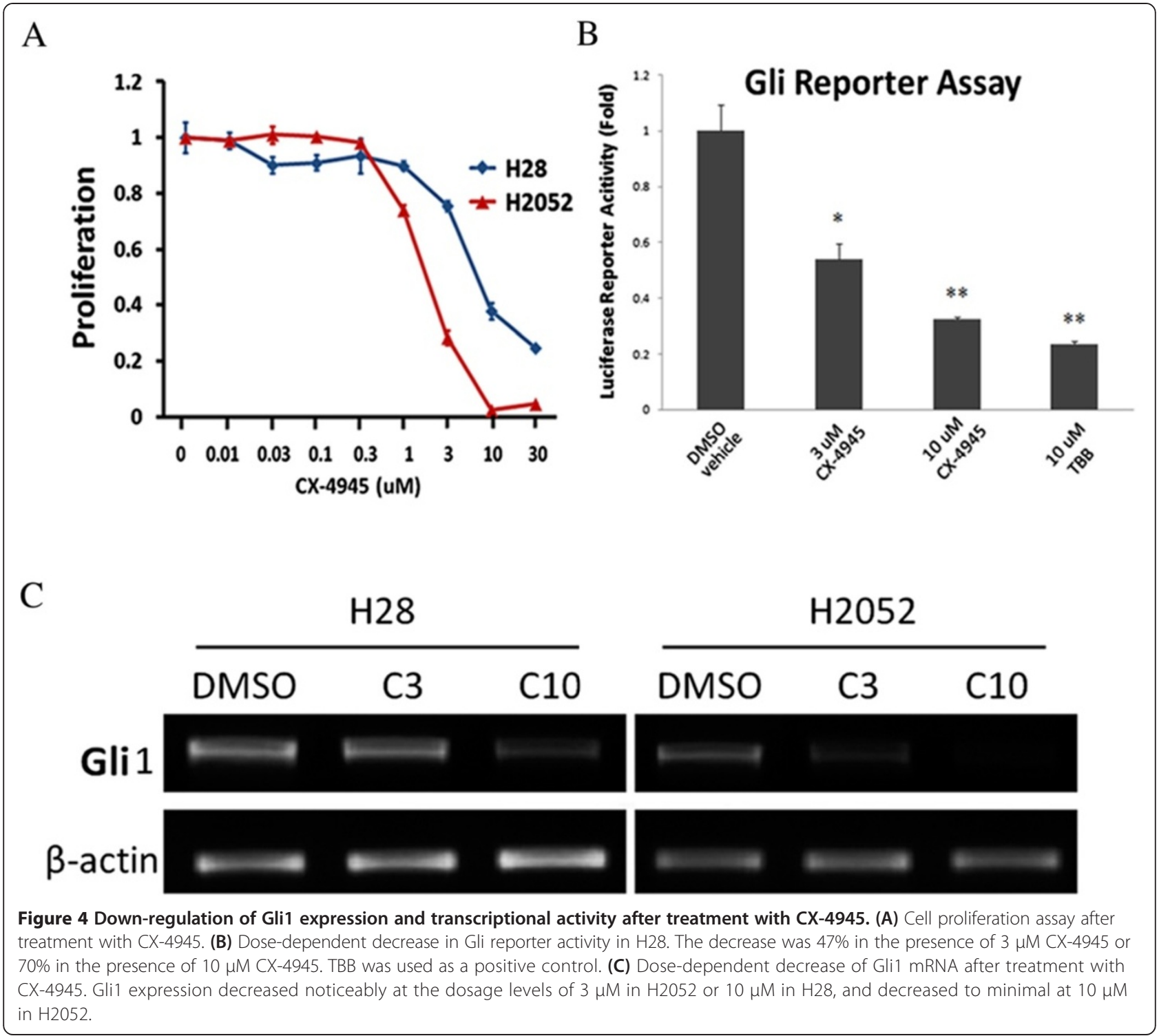

resulted in down-regulation of Gli1 expression and transcriptional activity. Finally, forced over-expression of CK2 $\alpha$ led to Gli1 transcriptional activation.

To date, there is no evidence for the expression status of CK2 in mesothelioma, although CK2 reportedly affects cell growth in several types of tumor. Our study shows the broad over-expression of CK2 $\alpha$ for the first time. Our findings suggest that CK2 may play an important role in mesothelioma pathogenesis and is a potential biomarker and therapeutic target for patients with mesothelioma. Further studies are warranted to show evidence for patients who may potentially benefit from CK2 inhibitors. CK2 inhibitors have not been extensively developed as therapeutic agents, partly because the ATP-binding pocket of CK2 is not as druggable as some other protein kinases [44-46]. To date, only one small-molecule CK2 inhibitor has been entered to clinical trials as a potential anticancer drug [47]. CX-4945, a highly selective CK2 small molecule inhibitor, is a promising first-in-class oral therapeutic agent that targets multiple human cancers. CX-4945 shows a favorable safety profile in Phase I clinical trials [48]. In addition, CIGB-300 (a synthetic peptide-based drug targeting the CK2 phosphoaceptor domain) has proved to be safe and of clinical benefit in Phase I cervical cancer trials [49].

Our study also demonstrates that Gli1 is over-expressed in mesothelioma, indicating the presence of an active $\mathrm{Hh}$ pathway. In several samples, the Gli1 mRNA level was more than 1000-fold greater than that in the normal pleura cell line LP9. This is consistent with findings from the recent study that first reported the role of aberrant Hh/Gli1 signaling in human mesothelioma [31]. The 
A

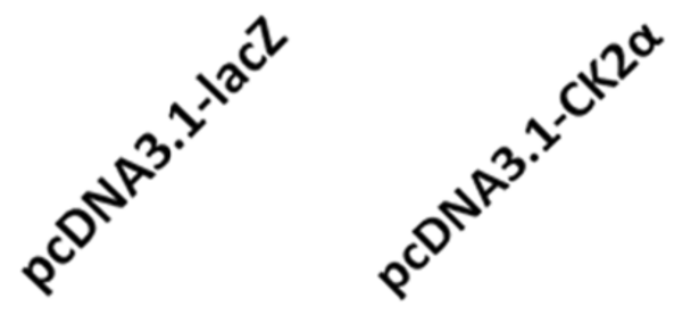

CK2 $\alpha$

GAPDH

B

\section{Gli Reporter Assay}

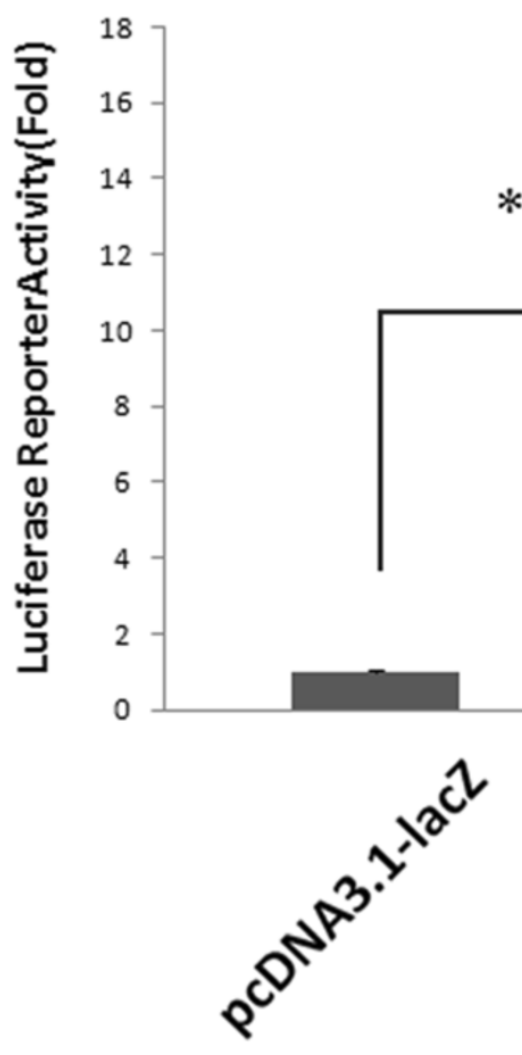

$* *$
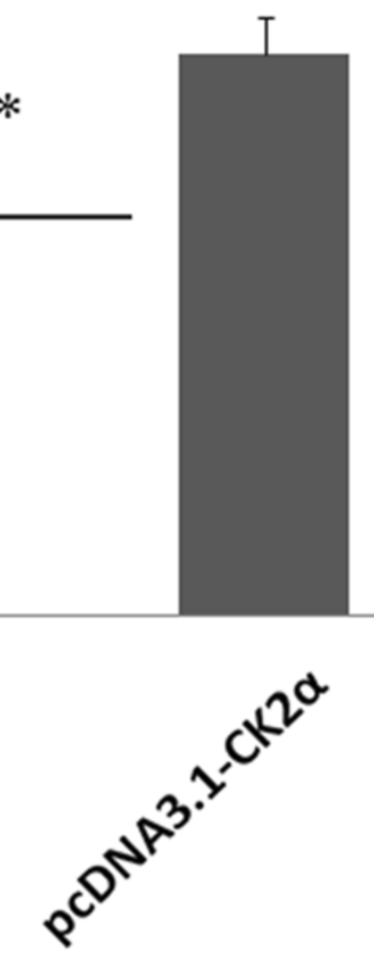

Figure 5 Up-regulation of Gli1 transcriptional activity in forced over-expressed CK2a H28 cells. (A) Over-expression of CK2a detected by Western blot. (B) Gli1 reporter assay. A significant (>10-fold) increase of the Gli1 transcriptional activity was shown in forced over-expressed CK2a H28 cells. 
Hedgehog pathway expression in mesothelioma tumors was recently analyzed using qRT-PCR, and SHH gene expression was only detected in tumor tissue but not in non-tumor pleural samples [31]. Moreover, in situ hybridization analysis of mesothelioma tumors showed similar results that the expression of $\mathrm{SHH}$ and $\mathrm{DHH}$ was mostly associated with the tumor cells [31]. Together, these results suggested that the Hh pathway expression on mesothelioma cells is mostly from autocrine expression of its ligands.

The Hh pathway plays key roles in maintaining cancer stem cells, and an antagonist of hedgehog inhibits tumor growth, indicating a new therapeutic approach on mesothelioma. However the druggable targets in the Hh pathway are very limited; to date, only one Hedgehog inhibitor GDC-0449 is approved by FDA for treatment of metastatic basal cell carcinoma. Recently, we have shown that $\mathrm{CK} 2 \alpha$ regulates $\mathrm{Hh} / \mathrm{Gli} 1$ signaling in human lung cancer, and silencing of CK $2 \alpha$ promotes Gli1 degradation in a time-course experiment [39]. CK2 $\alpha$ promotes Hh/Gli1 signaling by, at least in part, increasing Gli1 protein stability [39]. Another study showed that silencing CK2 $\alpha$ inhibited the expressions of Gli1 and Patched homolog 1 (PTCH1) in hepatocellular carcinoma, resulting in the inactivation of Hh signaling pathway [14]. The relationship between CK2 and Hh/Gli1 signaling in other types of cancer, including mesothelioma is still unknown.

In this study, correlated IHC staining of CK2 $\alpha$ and Gli1 in mesothelioma was demonstrated. For example, 32 of $38(84.2 \%)$ of moderate and strong positive $(++/+++)$ staining of Gli1 existed in the 52 samples with moderate and strong positive $(++/+++)$ staining of CK2 $\alpha$. Nine of thirteen $(69.2 \%)$ of strong positive $(+++)$ staining of Gli1 exited in the 30 samples with strong positive $(+++)$ staining of CK2 $\alpha$. We also analyzed CK $2 \beta$ expression in human mesothelioma tumors using IHC. The CK2 $\beta$ staining was compared with CK2 $\alpha$ and Gli1 expression in the same tumor samples $(n=61)$ (Additional file 1: Table S1). Association of CK2 $\alpha$ and Gli1 expression in the tumors was identified (Additional file 1: Table S2, $\mathrm{p}<0.05$, chi-square). Association of CK2 $\alpha$ and CK2 $\beta$ expression in the tumors was shown (Additional file 1: Table S3, $\mathrm{p}<0.05$, chisquare). However, association of CK2 $\beta$ and Gli1 expression in the tumors was not statistically significant (Additional file 1: Table S4, p >0.05, chi-square). Taken together, our results suggested that Gli1 expression is associated with CK2 $\alpha$ expression, but not CK2 $\beta$ expression, in the mesothelioma tumors. Furthermore, in the experimental studies of mesothelioma cell lines, CK2 $\alpha$ was suggested to positively regulate $\mathrm{Hh} / \mathrm{Gli1}$ signaling. Our study also suggests that CK2 is an additional target for the inhibition of Hh/Gli1 signaling in mesothelioma. Thus, CK2 inhibitors such as CX-4945 may be potentially beneficial for clinical treatment of patients with mesothelioma.

\section{Conclusions}

In summary, we report that CK2 is over-expressed and positively regulates $\mathrm{Hh} / \mathrm{Gli1}$ signaling in mesothelioma. However, the precise mechanism needs to be elucidated. Given the emerging importance of protein kinase CK2 and Hh/Gli1 signaling in tumor initiation and progression, our findings provide important new evidence for the potential benefits of CK2 inhibitors.

\section{Additional file}

\begin{abstract}
Additional file 1: Table S1. Comparison of IHC analysis of CK2a, CK2 $\beta$, Gli1 expression in mesothelioma tumors. Effects of CK2a inhibition or silencing in normal mesothelial LP9 cells. Table S2. Association analysis of CK2 $a$ and Gli1 expression in mesothelioma tumors ( $p<0.05$, Chi-square). Table S3. Association analysis of CK2 $a$ and $\mathrm{CK}_{2}$ _ expression in mesothelioma tumors ( $p<0.05$, Chi-square). Table $\mathbf{S 4}$. Association analysis of CK2_ and Gli1 expression in mesothelioma tumors ( $p>0.05$, Chi-square). Figure S1. (A) Down-regulation of two target genes of the Hh pathway (Gli1 and Ptch1) in LP9 cells, detected by quantitative RT- PCR, after CK2a siRNA treatment. (B) Cell proliferation assay after treatment with CX-4945.
\end{abstract}

\section{Abbreviations}

CK2: Casein kinase 2 or II (inappropriate name previously used); Hh: Hedgehog; Ptc: Patched; Smo: Smoothened; NSCLC: Non-small cell lung cancer; TBB: 4,5,6,7-tetrabromobenzotriazole; SP: Side population; ABCG2: ATP-binding cassette transporter member 2 of $G$ family protein.

\section{Competing interests}

The authors declare that they have no competing interests.

\section{Authors' contributions}

SZ conceived, designed and performed the experiments, analyzed the data and wrote the paper. YL performed the experiments, analyzed the data and wrote the paper. YW, LTF, IJK, AA analyzed the data. DH, BY, YD, GC performed the experiments. HJS contributed reagents/materials/analysis tools. ZX designed the experiments and analyzed the data. DMJ analyzed the data and revised the manuscript. LY conceived the experiments, analyzed the data and wrote the paper. All authors read and approved the final manuscript.

\section{Acknowledgements}

The present work was supported by NIH grant R01 CA140654-01A1 (LY). This work is also supported by the UALC foundation (Uniting Against Lung Cancer) (IJK). We thank Pamela Derish of the UCSF Department of Surgery for editorial assistance with the manuscript. We are grateful for support from the Kazan, McClain, Abrams, Fernandez, Lyons, Greenwood, Harley \& Oberman Foundation, Inc; the Estate of Robert Griffiths; the Jeffrey and Karen Peterson Family Foundation; Paul and Michelle Zygielbaum; the Estate of Norman Mancini; and the Barbara Isackson Lung Cancer Research Fund. We thank Lorretta Chan and Rick Baehnev for their important directions in staining.

\section{Author details}

${ }^{1}$ Department of Thoracic Surgery, The Fifth Hospital of Dalian, Dalian 116021, P.R. China. ${ }^{2}$ Thoracic Oncology Laboratory, Department of Surgery, Helen Diller Family Comprehensive Cancer Center, University of California San Francisco, San Francisco, CA 94143, USA. ${ }^{3}$ Department of Surgery, Helen Diller Family Comprehensive Cancer Center, University of California San Francisco, San Francisco, CA 94143, USA. ${ }^{4}$ Department of Thoracic Surgery, Beijing Chao-Yang Hospital, Affiliated with Capital University of Medical Science, Beijing, P.R. China. ${ }^{5}$ Division of Diagnostic Pathology, Helen Diller Family Comprehensive Cancer Center, University of California San Francisco, San Francisco, CA 94143, USA. ${ }^{6}$ Tissue Core, Comprehensive Cancer Center, University of California San Francisco, San Francisco, CA 94143, USA. 
Received: 14 August 2014 Accepted: 22 October 2014

Published online: 25 November 2014

\section{References}

1. Meggio F, Pinna LA: One-thousand-and-one substrates of protein kinase CK2? FASEB J 2003, 17:349-368.

2. Raaf J, Bischoff N, Klopffleisch K, Brunstein E, Olsen BB, Vilk G, Litchfield DW Issinger OG, Niefind K: Interaction between CK2alpha and CK2beta, the subunits of protein kinase CK2: thermodynamic contributions of key residues on the CK2alpha surface. Biochemistry 2011, 50:512-522.

3. Guo C, Yu S, Davis AT, Ahmed K: Nuclear matrix targeting of the protein kinase CK2 signal as a common downstream response to androgen or growth factor stimulation of prostate cancer cells. Cancer Res 1999, 59:1146-1151.

4. Buchou T, Vernet M, Blond O, Jensen HH, Pointu H, Olsen BB, Cochet C, Issinger OG, Boldyreff B: Disruption of the regulatory beta subunit of protein kinase CK2 in mice leads to a cell-autonomous defect and early embryonic lethality. Mol Cell Biol 2003, 23:908-915.

5. Ahmad KA, Wang G, Unger G, Slaton J, Ahmed K: Protein kinase CK2-a key suppressor of apoptosis. Adv Enzyme Regul 2008, 48:179-187.

6. Dominguez I, Sonenshein GE, Seldin DC: Protein kinase CK2 in health and disease: CK2 and its role in Wnt and NF-kappaB signaling: linking development and cancer. Cell Mol Life Sci 2009, 66:1850-1857.

7. Trembley JH, Wang G, Unger G, Slaton J, Ahmed K: Protein kinase CK2 in health and disease: CK2: a key player in cancer biology. Cell Mol Life SCi 2009, 66:1858-1867.

8. Piazza FA, Ruzzene M, Gurrieri C, Montini B, Bonanni L, Chioetto G, Di Maira G, Barbon F, Cabrelle A, Zambello R, Adami F, Trentin L, Pinna LA, Semenzato G: Multiple myeloma cell survival relies on high activity of protein kinase CK2. Blood 2006, 108:1698-1707.

9. Wang G, Ahmad KA, Harris NH, Ahmed K: Impact of protein kinase CK2 on inhibitor of apoptosis proteins in prostate cancer cells. Mol Cell Biochem 2008, 316:91-97.

10. Martins $L R$, Lucio $P$, Silva MC, Anderes KL, Gameiro P, Silva MG, Barata JT: Targeting CK2 overexpression and hyperactivation as a novel therapeutic tool in chronic lymphocytic leukemia. Blood 2010, 116:2724-2731.

11. Laramas M, Pasquier D, Filhol O, Ringeisen F, Descotes $J \mathrm{~L}$, Cochet C: Nuclear localization of protein kinase CK2 catalytic subunit (CK2alpha) is associated with poor prognostic factors in human prostate cancer. Eur J Cancer 2007, 43:928-934.

12. Kim JS, Eom JI, Cheong JW, Choi AJ, Lee JK, Yang WI, Min YH: Protein kinase CK2alpha as an unfavorable prognostic marker and novel therapeutic target in acute myeloid leukemia. Clin Cancer Res 2007, 13:1019-1028

13. Lin $K Y$, Fang $C L$, Chen $Y$, Li CF, Chen $S H$, Kuo $C Y$, Tai C, Uen YH: Overexpression of nuclear protein kinase CK2 Beta subunit and prognosis in human gastric carcinoma. Ann Surg Oncol 2010, 17:1695-1702.

14. Wu D, Sui C, Meng F, Tian X, Fu L, Li Y, Qi X, Cui H, Liu Y, Jiang Y: Stable knockdown of protein kinase CK2-alpha (CK2alpha) inhibits migration and invasion and induces inactivation of hedgehog signaling pathway in hepatocellular carcinoma Hep G2 cells. Acta Histochem 2014. doi:10.1016/j.acthis.2014.06.001.

15. Duncan JS, Litchfield DW: Too much of a good thing: the role of protein kinase CK2 in tumorigenesis and prospects for therapeutic inhibition of CK2. Biochim Biophys Acta 2008, 1784:33-47.

16. Guerra B: Protein kinase CK2 subunits are positive regulators of AKT kinase. Int J Oncol 2006, 28:685-693.

17. Beachy PA, Karhadkar SS, Berman DM: Tissue repair and stem cell renewal in carcinogenesis. Nature 2004, 432:324-331.

18. Ingham PW, McMahon AP: Hedgehog signaling in animal development: paradigms and principles. Genes Dev 2001, 15:3059-3087.

19. Ingham PW, Nakano Y, Seger C: Mechanisms and functions of Hedgehog signalling across the metazoa. Nat Rev Genet 2011, 12:393-406.

20. Ng JM, Curran T: The Hedgehog's tale: developing strategies for targeting cancer. Nat Rev Cancer 2011, 11:493-501.

21. Takebe N, Harris PJ, Warren RQ, Ivy SP: Targeting cancer stem cells by inhibiting Wnt, Notch, and Hedgehog pathways. Nat Rev Clin Oncol 2011, 8:97-106.

22. Ruiz i Altaba A: Therapeutic inhibition of Hedgehog-GLI signaling in cancer: epithelial, stromal, or stem cell targets? Cancer Cell 2008, 14:281-283.
23. Kinzler KW, Bigner SH, Bigner DD, Trent JM, Law ML, O'Brien SJ, Wong AJ, Vogelstein B: Identification of an amplified, highly expressed gene in a human glioma. Science 1987, 236:70-73.

24. Dahmane N, Lee J, Robins P, Heller P, Ruiz i Altaba A: Activation of the transcription factor Gli1 and the Sonic hedgehog signalling pathway in skin tumours. Nature 1997, 389:876-881.

25. Epstein EH: Basal cell carcinomas: attack of the hedgehog. Nat Rev Cancer 2008, 8:743-754

26. Nilsson M, Unden AB, Krause D, Malmqwist U, Raza K, Zaphiropoulos PG, Toftgard R: Induction of basal cell carcinomas and trichoepitheliomas in mice overexpressing GLI-1. Proc Natl Acad Sci U S A 2000, 97:3438-3443.

27. Ismail-Khan R, Robinson LA, Williams CC Jr, Garrett CR, Bepler G, Simon GR: Malignant pleural mesothelioma: a comprehensive review. Cancer Control 2006, 13:255-263.

28. Catalano A, Rodilossi S, Rippo MR, Caprari P, Procopio A: Induction of stem cell factor/c-Kit/slug signal transduction in multidrug-resistant malignant mesothelioma cells. J Biol Chem 2004, 279:46706-46714.

29. Uematsu K, Kanazawa S, You L, He B, Xu Z, Li K, Peterlin BM, McCormick F, Jablons DM: Wnt pathway activation in mesothelioma: evidence of Dishevelled overexpression and transcriptional activity of beta-catenin. Cancer Res 2003, 63:4547-4551.

30. Abutaily AS, Collins JE, Roche WR: Cadherins, catenins and APC in pleural malignant mesothelioma. J Pathol 2003, 201:355-362.

31. Shi Y, Moura U, Opitz I, Soltermann A, Rehrauer H, Thies S, Weder W, Stahel RA, Felley-Bosco E: Role of hedgehog signaling in malignant pleural mesothelioma. Clin Cancer Res 2012, 18:4646-4656.

32. Zhang Y, He J, Zhang F, Li H, Yue D, Wang C, Jablons DM, He B, Lui N: SMO expression level correlates with overall survival in patients with malignant pleural mesothelioma. J Exp Clin Cancer Res 2013, 32:7.

33. Li T, Li H, Wang Y, Harvard C, Tan JL, Au A, Xu Z, Jablons DM, You L: The expression of CXCR4, CXCL12 and CXCR7 in malignant pleural mesothelioma. J Pathol 2011, 223:519-530.

34. Sasaki H, Hui C, Nakafuku M, Kondoh H: A binding site for Gli proteins is essential for HNF-3beta floor plate enhancer activity in transgenics and can respond to Shh in vitro. Development 1997, 124:1313-1322.

35. Dhoot GK, Gustafsson MK, Ai X, Sun W, Standiford DM, Emerson CP Jr: Regulation of Wnt signaling and embryo patterning by an extracellular sulfatase. Science 2001, 293:1663-1666.

36. Yuan Z, Goetz JA, Singh S, Ogden SK, Petty WJ, Black CC, Memoli VA, Dmitrovsky E, Robbins DJ: Frequent requirement of hedgehog signaling in non-small cell lung carcinoma. Oncogene 2007, 26:1046-1055.

37. Scaglioni PP, Yung TM, Cai LF, Erdjument-Bromage H, Kaufman AJ, Singh B, Teruya-Feldstein J, Tempst P, Pandolfi PP: A CK2-dependent mechanism for degradation of the PML tumor suppressor. Cell 2006, 126:269-283.

38. Zhang S, Long H, Yang YL, Wang Y, Hsieh D, Li W, Au A, Stoppler HJ, Xu Z, Jablons DM, You L: Inhibition of CK2alpha down-regulates Notch1 signalling in lung cancer cells. J Cell Mol Med 2013, 17:854-862.

39. Zhang S, Wang Y, Mao JH, Hsieh D, Kim IJ, Hu LM, Xu Z, Long H, Jablons DM, You L: Inhibition of CK2alpha down-regulates Hedgehog/Gli signaling leading to a reduction of a stem-like side population in human lung cancer cells. PLoS One 2012, 7:e38996.

40. Trembley JH, Unger GM, Korman VL, Tobolt DK, Kazimierczuk Z, Pinna LA, Kren BT, Ahmed K: Nanoencapsulated anti-CK2 small molecule drug or siRNA specifically targets malignant cancer but not benign cells. Cancer Lett 2012, 315:48-58.

41. Seeber $\mathrm{S}$, Issinger $\mathrm{OG}, \mathrm{Holm} \mathrm{T}$, Kristensen LP, Guerra B: Validation of protein kinase CK2 as oncological target. Apoptosis 2005, 10:875-885.

42. Pierre F, Chua PC, O'Brien SE, Siddiqui-Jain A, Bourbon P, Haddach M, Michaux J, Nagasawa J, Schwaebe MK, Stefan E, Vialettes A, Whitten JP, Chen TK, Darjania L, Stansfield R, Anderes K, Bliesath J, Drygin D, Ho C, Omori M, Proffitt C, Streiner N, Trent K, Rice WG, Ryckman DM: Discovery and SAR of 5-(3-chlorophenylamino)benzo[c][2,6]naphthyridine-8-carboxylic acid (CX-4945), the first clinical stage inhibitor of protein kinase CK2 for the treatment of cancer. J Med Chem 2011, 54:635-654.

43. Sarno S, Reddy H, Meggio F, Ruzzene M, Davies SP, Donella-Deana A, Shugar D, Pinna LA: Selectivity of 4,5,6,7-tetrabromobenzotriazole, an ATP site-directed inhibitor of protein kinase CK2 ('casein kinase-2'). FEBS Lett 2001, 496:44-48.

44. Sarno S, Pinna LA: Protein kinase CK2 as a druggable target. Mol Biosyst 2008, 4:889-894

45. Cozza G, Meggio F, Moro S: The dark side of protein kinase CK2 inhibition. Curr Med Chem 2011, 18:2867-2884. 
46. Cozza G, Bortolato A, Moro S: How druggable is protein kinase CK2? Med Res Rev 2010, 30:419-462.

47. Cozza G, Pinna LA, Moro S: Kinase CK2 inhibition: an update. Curr Med Chem 2013, 20:671-693.

48. Pierre F, Chua PC, O'Brien SE, Siddiqui-Jain A, Bourbon P, Haddach M, Michaux J, Nagasawa J, Schwaebe MK, Stefan E, Vialettes A, Whitten JP, Chen TK, Darjania L, Stansfield R, Bliesath J, Drygin D, Ho C, Omori M, Proffitt C, Streiner N, Rice WG, Ryckman DM, Anderes K: Pre-clinical characterization of CX-4945, a potent and selective small molecule inhibitor of CK2 for the treatment of cancer. Mol Cell Biochem 2011, 356:37-43.

49. Perea SE, Baladron I, Garcia Y, Perera Y, Lopez A, Soriano JL, Batista N, Palau A, Hernandez I, Farina H, Garcia I, Gonzalez L, Gil J, Rodriguez A, Solares M, Santana A, Cruz M, Lopez M, Valenzuela C, Reyes O, López-Saura PA, González CA, Diaz A, Castellanos L, Sanchez A, Betancourt L, Besada V, González LJ, Garay H, Gómez R, et al: CIGB-300, a synthetic peptide-based drug that targets the CK2 phosphoaceptor domain. Translational and clinical research. Mol Cell Biochem 2011, 356:45-50.

doi:10.1186/s13046-014-0093-6

Cite this article as: Zhang et al:: CK2a, over-expressed in human malignant pleural mesothelioma, regulates the Hedgehog signaling pathway in mesothelioma cells. Journal of Experimental \& Clinical Cancer Research 2014 33:93.

\section{Submit your next manuscript to BioMed Central and take full advantage of:}

- Convenient online submission

- Thorough peer review

- No space constraints or color figure charges

- Immediate publication on acceptance

- Inclusion in PubMed, CAS, Scopus and Google Scholar

- Research which is freely available for redistribution 